\title{
Recognition of indigenous water values in Australia's Northern Territory: current progress and ongoing challenges for social justice in water planning.
}

Sue Jackson ${ }^{*} \dagger$ and Marcus Barber ${ }^{\ddagger}$

\section{Acknowledgements}

We thank the Aboriginal and non-Aboriginal research participants in this study for their time and patience. The research was funded by the Water for a Healthy Country Flagship of the CSIRO and the Northern Australia Water Futures Assessment (NAWFA) and authorized through the Northern Land Council. We thank CSIRO, NAWFA, and NLC staff for their support. We thank multiple reviewers of this research for their comments and accept responsibility for any remaining errors.

\section{Biographies}

Dr Sue Jackson is a geographer with twenty years' experience researching the social dimensions of natural resource management in Australia. Dr Jackson is a Principal Research Fellow at Griffith University's Australian Rivers Institute and is a member of the Research Executive of TRaCK - the Tropical Rivers and Coastal Knowledge Research Hub - which is a large multidisciplinary consortium operating throughout northern Australia. She has undertaken many research projects for indigenous communities, including social impact

\footnotetext{
* Principal Research Fellow, Australian Rivers Institute, Griffith University.

Corresponding author: sue.jackson@ griffith.edu.au

At the time the research was conducted, Dr. Jackson was employed with CSIRO's Division of Ecosystem Sciences.

${ }^{\dagger}$ Tropical Rivers and Coastal Knowledge Research Hub, Darwin, NT, Australia

* Marcus Barber, Research Scientist, CSIRO Ecosystem Sciences.
} 
studies, and has authored over 90 scientific papers, book chapters, reports and conference papers.

Dr Marcus Barber is an anthropologist with fifteen years research experience in the environmental and social sciences. He works as research scientist with the CSIRO, the research agency of the Australian government, on natural resource management and indigenous rights projects in Northern Australia. He is the author or editor of more than 20 scientific papers, edited books, and reports.

\section{Abstract}

This paper details indigenous Australian water values and interests, highlights progress towards improved distributive outcomes from water planning and analyses the remaining challenges in meeting indigenous aspirations for cultural recognition. It describes the significance of water to indigenous people living in the Roper River of Australia's Northern Territory; reports on innovations in water allocation planning processes aimed at accommodating that significance; and analyses the implications of this case study for water planning generally. We describe rich cultural and historical connections with water places; protocols governing human conduct towards water; custodial assertions regarding the need for 'water for the country'; distinctive values relating to riparian vegetation; and claims of ownership and economic rights in contemporary water allocations. Current water planning objectives such as sustainable development, protection for groundwater dependent ecosystems, and protection of indigenous values accord with contemporary indigenous perspectives in the Roper, and in a national first, the local water plan specifically proposes reserving a significant water allocation for commercial use by indigenous people. Yet that allocation is seen as unjust from a local perspective, and further analysis demonstrates a 
range of other limitations: the scale and boundedness of the demarcated plan area; the neglect of riparian vegetation management; insufficient resourcing of local indigenous capacity; mismatches in planning and local governance structures; and the broader question of whether a rationalist planning process can simultaneously advance indigenous claims for recognition, equity in distributions and parity in participation.

Keywords: indigenous water values, customary water governance, water planning, indigenous rights, water justice, Roper River.

\section{Introduction}

The 2004 National Water Initiative (NWI) represents the first major Australian natural resource policy to recognise indigenous interests in water (Australian Government, 2004). Since it was signed, Australian Federal and State jurisdictions have been grappling with how to appropriately recognise the values and interests of indigenous people in water allocation plans. The progress achieved and the ongoing challenges provide important insights for other jurisdictions engaged with similar issues, particularly those nations and regions transforming their water governance arrangements (Godden and Foerster, 2012). This paper focuses on the case of the upper Roper River in the Northern Territory (Barber and Jackson 2011a), and complements a number of other studies by the authors examining Australian indigenous water values and systems of customary governance, as well as their articulation with state systems of allocation and management (Barber and Jackson 2012, 2011b; Cooper and Jackson 2008; Jackson, 2011; Jackson and Altman 2009; Jackson and Langton 2012; Jackson et al. 2012). 
This work, and the recent work of others researching this area in Australia (Altman, 2004; Altman and Branchut, 2008; Behrendt and Thompson, 2004; Cranney and Tan, 2012; Mooney and Tan, 2012; Weir, 2009), describes the institutions and negotiating arenas through which indigenous peoples seek to establish the legitimacy of their water related values, ethics and practices and to define, increase or influence their access to water. All these authors observe a high degree of contestation between indigenous and non-indigenous people over key water management institutions, particularly over property rights and water resource development scenarios during a period of rapid governance transformation (Altman, 2004; Bark et al., 2012; Jackson, 2011; Morgan et al., 2004; Weir, 2009). Furthermore, this Australian research confirms the conclusion one draws from the international literature: the existence of parallel indigenous governance systems presents a challenge for nations engaged in reforming their water sectors (Bruns et al., 2005; Burchi, 2010). In order to meet aspirations for sustainable livelihoods and water justice, local systems of resource governance need to be well understood.

Water reform gained momentum in Australia because of the water management crisis in its agricultural regions, in part as a result of over-allocation of entitlements (Hussey and Dovers, 2007). Over two decades, reforms have aimed for a nationally-compatible water market, regulatory and planning-based system based on entitlements that are exclusive, tradeable (where relevant), enforceable, and defined separately from land as a perpetual share of a specified water resource (Tan et al., 2012). Water planning is a resource allocation institution that coordinates water use and prioritises preferred water uses by regulating socially accepted claims to water. In regional Australia it has been instituted to both resolve trade-offs between competing water uses and involve users in water governance (Tan et al., 2012). 
Given the marginalised status of the minority indigenous population, it is important to understand how it fares in water planning processes, particularly as water become increasingly scarce and the water economy is further developed with market-based incentive structures such as pricing and trading (Connell et al., 2005). For this reason, Australian water planning has been a key focus for applied research relating to indigenous water rights and values. Detailed ethnographic research has explored the range of religious, cultural, and cosmological connections between indigenous people and their estates, but more empirical research and extended analysis is required. For water planning to be successful, natural resource management practitioners need to better understand indigenous water values, interests, connections and relationships at the appropriate scale (Jackson et al., 2012). Planners need legal instruments to provide secure entitlements to indigenous people and they also need to reflect on the cultural premises of rationalist planning frameworks and methods so that they can critically evaluate the capacity of resource management institutions to accommodate multiple and often conflicting ways of valuing (Richardson, 2005).

The case of the upper Roper River in the Northern Territory provides a useful way of assessing current trends in resolving inter-cultural water conflicts and progress towards social justice in water planning. Rich ethnographic and archival material highlights the multifaceted significance of water to indigenous people; novel aspects of the first water plan for the area demonstrates progress in accommodating that significance through a redistributive mechanism, and further analysis demonstrates some of the remaining challenges. Although the Roper River region is characterised by a set of circumstances particular to the Northern Territory, where statutory and common law land claims have resulted in very high rates of indigenous land ownership and therefore relatively stronger bargaining power, the precedent of reserving a substantial volume of water for indigenous people to use for economic 
purposes (called the Strategic Indigenous Reserve (SIR)) is nonetheless nationally significant. Further, the Roper River case can be viewed a practical and powerful means of accommodating customary governance of water outside the protracted and often disappointing process of judicial action (Tehan, 2003; McAvoy, 2005).

However, local reservations and criticisms exist regarding the adequacy of the proposed SIR, and less progress is evident in either incorporating indigenous preferences in the formulation of environmental management goals or in non-indigenous understanding of indigenous ontology and cosmology more generally. Therefore the paper uses local case study material to highlight three areas of ongoing national policy attention (i) measures to ensure that indigenous people benefit from water resource development (through resource rights); (ii) ways of recognising indigenous cultural perspectives in water plans; and (iii) processes and mechanisms to improve indigenous participation in water management. We apply a social justice framework developed by Nancy Fraser $(1995 ; 2009)$ to support our argument that planning needs to simultaneously attend to the socio-economic, cultural and political dimensions of water justice.

Prior to describing our study site and outlining our methods of data collection, it is first important to examine trends in Australian water justice and scholarly debates concerning social justice.

\section{Water Rights, Planning and Social Justice}

The impetus for including indigenous water rights and interests in the 2004 water policy was judicial and legislative recognition of native title during the 1990s. The landmark Mabo High 
Court decision and the subsequent Native Title Act (NTA) 1993 constituted legal acknowledgment of pre-existing indigenous occupation of land, and the scope was defined to include rights over waters located within traditional estate boundaries. The decision confirmed Crown ownership of water and minerals, while guaranteeing rights to customary use of resources for non-commercial purposes (e.g. hunting, gathering and fishing). As well, a right to protect sites or areas of significance that include waters has been recognised as a native title right. Judicial interpretation of native title confirmed it as a bundle of rights, including various rights to water, and the implications for water administration and management could not be ignored. The NWI Agreement requires jurisdictions to provide for indigenous access to water resources through planning processes and inclusion of indigenous customary, social and spiritual objectives in water plans (Australian Government, 2004). Native title interests in water are to be taken into account and indigenous water use assessed and addressed in plans.

Despite the legal reforms and subsequent policy and planning progress, implementation of the indigenous provisions of the policy has been very slow across Australia (NWC, 2011). Research to date suggests that indigenous people still face considerable uncertainty with regard to their water property rights and that current arrangements are inequitable (Altman and Branchut, 2008; MacAvoy, 2006; MacFarlane, 2004; O’Donnell, 2011). With the market-based water rights system now well-established in southern Australian regions, this inequity has become evident, especially in agricultural areas where the water resource is fully or over-allocated (Jackson, 2011). Jackson and Langton (2012) compared indigenous land ownership and water entitlements and, in doing so, demonstrated the extent of the inequity: indigenous people own more than 20 per cent of the country's land mass (Altman et al., 
2007) while indigenous specific water entitlements are at present estimated at less than 0.01 per cent of Australian water diversions.

More empirical studies of the political economy of water are needed to understand the factors that affect patterns of water distribution and any regional differences in the degree to which indigenous people access water. As property is created in water and new institutions are established to commercialise water use in northern and remote parts of Australia, ensuring that transformations in water governance do not entrench inequities between indigenous and non-indigenous people is a key aspect of the water policy agenda. Indigenous advocates are especially keen to see that access is open to indigenous communities for commercial activities (Altman, 2004).

Responding to this challenge, a number of progressive policy initiatives are under development. In the past decade, opportunities for indigenous participation in multistakeholder water planning forums has grown across the country, with notable initiatives being the indigenous fora that contributed to the development of the Murray Darling Basin Plan and the First Peoples Water Engagement Council, which has advised the Federal Water Minister since 2010 (FPWEC, 2012). Australia's National Water Commission has supported research into NWI implementation and funded two national indigenous water planning fora (2009 and 2012) which were held with indigenous advocates, water planners and researchers to discuss principles and actions required to progress the reform agenda implicit in the NWI. Nevertheless, despite such progress towards incorporating indigenous cultural perspectives in planning debates, substantial institutional impediments of a legal (O’Donnell, 2011; Tan and Jackson, 2013), political-economic (Altman and Branchut, 2008; Barber and Jackson, 2011a) and epistemological nature (Jackson, 2006; Weir, 2009) continue to constrain indigenous 
access to water and limit the extent to which indigenous values and management perspectives are empowered by water plans.

Indigenous claims for equitable distributions of water entitlements come with an expectation of state recognition of customary systems of water governance, including indigenous environmental philosophies, and parity of participation in state water governance arrangements. We align these policy goals with the tripartite social justice schema theorised by Nancy Fraser $(1995 ; 2009)$ who argues that 'theories of justice must become threedimensional, incorporating the political dimension of representation alongside the economic dimension of distribution and the cultural dimension of recognition' (2009: 15).

Conventional social justice theories advocate equity in societal patterns of distribution as a measure of justice, however, the demands of cultural and social group-based claims for recognition of their difference has strained the conceptualisations of justice which are predicated on unity, impartiality, commonality and equity in distribution of material goods (Young, 1990; Lake, 1996). Cultural or symbolic forms of injustice are rooted in social patterns of representation, interpretation, and communication (Fraser, 1995, p. 71) and include being subjected to patterns of representation held by a majority culture, nonrecognition and disrespect.

Fraser's early work explicated a 'redistribution- recognition dilemma' whereby 'people who are subject to both cultural injustice and economic injustice need both recognition and redistribution' (1995, p. 74) and her initial analytical model was designed to articulate the interactions and tensions between political efforts to achieve redistribution and recognition. Accordingly, 'justice today requires both redistribution and recognition (1995, p. 69, 
emphasis in original), although her main interest then lay in pursuing the circumstances under which a politics of recognition can help support a politics of redistribution (1995, p. 70).

More recently, in light of globalisation's impact on how we conceive the modern territorial state, Fraser (2009) has taken her early two-dimensional view of justice further. Arguing that her previous theory had 'failed to appreciate the relative autonomy of inequities rooted in the political constitution of society, as opposed to the economic structure or the status order', (2009 p.6), she seeks to attend to the scope of the state's jurisdiction and the decision rules by which contestation is structured (2009 p. 17). The political dimension of Fraser's justice theory is thus centred on issues of membership and procedure.

In our case, resource rights such as indigenous water entitlements represent the 'social politics of equality' and measures to incorporate indigenous cultural perspectives in water plans align with the cultural politics of 'identity, difference and recognition' (1995, p. 71). The allocation planning process and its participatory procedures and mechanism, the Water Advisory Committee, represent the political dimension which 'furnishes the stage on which struggles over distribution and recognition are carried out' (2009 p. 17). We apply Fraser's justice theory to the Roper River but with an accent on two inter-related questions: can a politics of water rights redistribution support the recognition of cultural difference and, if not, might a reframing of political representation in this case assist in addressing maldistribution and misrecognition? Fraser's analysis was selected for two reasons. Firstly, the schema invites consideration of the often neglected cultural dimensions of water planning (Syme and Hatfield-Dodds, 2007), alongside often interdependent socio-economic ones (Jackson and Altman, 2009; Jackson and Langton, 2012). Second, it is well-suited to an indigenous context 
where advocates have a conceptualisation of justice that is broader than achieving equity and parity amongst all Australians and includes access to decision-making and influential forms of representation.

\section{Study Site and Methods}

Study site

Situated in Australia's tropical north with its headwaters approximately $400 \mathrm{~km}$ southeast of Darwin, the Roper River is a large, perennial flowing river with a total catchment area of $81,794 \mathrm{~km}^{2}$ (see Figure 1). The region's monsoonal climate has pronounced wet and dry seasons and warm temperatures throughout the year, resulting in a highly variable river flow pattern.

Insert Figure 1 somewhere around here

The thermal pools, natural springs, large wetlands and the riparian landscapes of the Roper River are sustained by groundwater which also provides a high quality and easily accessible resource for expanding industries, including irrigated agriculture and pastoral operations. Growth in water extraction in the upper catchment zone encompassing the town of Mataranka precipitated a water planning process in 2008. The water plan was designed to provide security for water users and appropriate guidelines for the assessment of groundwaterdependent ecosystems in the area (DNRETAS, 2009a).

Mataranka is the regional centre and the geographic focus of both the archival and field research was the area incorporating Mataranka, Elsey National Park, the indigenous township 
of Jilkmingan, and the large and historically significant pastoral station called Elsey Station, which is now indigenous-owned. The focal area is a smaller area than the overall water planning area (see Figure 1), but it contains the major sites of active water management discussed here, the origin springs for the Roper River and many key water places for both past and present indigenous people.

Indigenous people comprise close to $70 \%$ of the regional population and are major landowners holding title to close to $70 \%$ of the land area (NAILSMA, 2011) as a result of land restitution schemes enabled by the Aboriginal Land Rights (Northern Territory) Act 1976 and native title processes. Indigenous lands support a variety of uses, mainly as community living areas with some areas (such as Elsey Station) being utilised for pastoralism which is the dominant land use in the catchment. Freehold title allows unfettered use rights for non-commercial purposes and gives traditional land owners control over land access and use. All regional industries including pastoralism, mining, fishing and tourism rely on the region's water resources.

Space limitations constrain the level of literature and wider historical detail that can be provided here, but the recent ethnographic record about this area is considerable and of high quality (Merlan, 1978; Merlan, 1981; Merlan, 1982; Merlan, 1986; Merlan, 1987; Merlan, 1993; Merlan ,1996). A key reason for this is that, although indigenous people residing in the area were subject to considerable violence in the early years of colonisation and pastoral land use (Merlan, 1978) they were never forcibly relocated en masse to missions or other locations. Rather the pastoral industry found indigenous labour useful and accommodated ongoing indigenous residence, particularly at Elsey Station. Elsey was the setting for the 
highly successful early $20^{\text {th }}$ century novel, 'We of the Never Never' (Gunn, 2003 [1908]) as well as subsequent historical works (Thonemann, 1949; Merlan 1996).

\section{Methods}

The research was carried out under an agreement between the Commonwealth Scientific Industrial Research Organisation (CSIRO) and the Northern Land Council (NLC), which represents the traditional owners of the Roper River area. The research which was conducted during 2010 and 2011 involved archival and literature searches, semi-structured interviews, and participant observation at meetings and field excursions. All interviewees participated following a process of free prior informed consent as per CSIRO's Human Ethics Research Guidelines. Research participants were identified using the snowball method (Patton, 1990) in which a list of senior owners provided by the NLC was augmented by recommendations from those already contacted. The principles used to identify potential interviewees included seniority, group identity, knowledge of the country, place and duration of residence, recent profile in speaking about water issues, and expected availability for interview. In total, 33 people meeting the requirements above were approached and given the opportunity to participate and 18 were formally interviewed. The majority of these people were from or strongly related to local language-based territorial groupings: Mangarrayi, Yangman, and Wubulawun peoples, as well as people with associations to what is known as the Beswick Land Trust area, and a significant number were members of the Mataranka Traditional Owner Water Allocation Reference Group established by the NLC to ensure traditional owners participated in the development of the water plan. Rather than relying solely on land ownership as the criterion for interview, we selected a number of long term indigenous residents of the area because the research focus included local ecological history and future development aspirations. 


\section{Results}

The significance of water to indigenous people in the upper Roper River

For the indigenous people of the upper Roper River region, particularly those from the Mangarrayi and Yangman language groups, continuous occupation has generated a distinct and strong attachment to land and waterscapes as well as considerable knowledge of its local features. The 'Big River Country' as it is known (Merlan, 1996) is enlivened by the Dreaming creators and the spirits of ancestors and governed by principles of traditional ownership and management. From an indigenous perspective, the country and the places it contains are active participants in the life of human beings, responding to events and actions in the world, particularly the actions of those people with whom it is ancestrally connected.

The study site contains a significant number of water sources and water places, as well as a rich set of stories, Dreamings, and historical associations important to local people. These in turn have generated protocols regarding human conduct and a concern with the maintenance of 'water for the country' - water in springs and creeks which maintain healthy floral, faunal, and human populations. We note the distinctive values placed upon riparian vegetation and highlight claims of ownership and of economic rights asserted in water sharing discussions about the Plan. Further information about water-related topics discussed in the field and detailed description of their social significance can be found in (Barber and Jackson, 2011a). Alongside their immediate specificity for the Roper context, the local features identified here demonstrate the wider role of water as creative and sustaining, as socially unifying, as implicated in ethics and reciprocal responsibility, as an integral aspect of systems of rights 
and ownership, and as fundamentally and inseparably intertwined with the wider landscape. Below we summarise key themes emerging from the ethnographic data.

Ancestral accounts: water as creative and sustaining

Consistent with the accounts from other Australian regions (Barber, 2005; Barber and Jackson, 2011b; Barber and Rumley, 2003; Cooper and Jackson, 2008; Jackson, 2006; Langton, 2002; Langton, 2006; Rose, 2004; Strang, 2001; Strang 2002; Toussaint, Sullivan et al. 2005), indigenous people in the upper Roper have important ancestral accounts, popularly known as Dreamings, in which creator beings were responsible for giving form to the present state of the world and continue to live in it. The Dreaming is an ongoing reality as well as a time in the distant past, and the beings that inhabit the Dreaming are also inhabitants of the contemporary world. Such beings are often associated with water, and the aquatic orientation of key sites was noted in the findings from the land claim:

There is a heavy concentration of sites along the Roper River, where permanent water is available. Other sites tend to be associated with permanent waterholes in the ephemeral waterways. There is no neat pattern of Dreaming tracks associated with sites. Rather, Dreaming tracks intertwine.

(Commonwealth of Australia, 1997, p.113)

The Dreaming narratives both interpret and reflect the significance of water and water features, as the kangaroo (Garawi) story associated with a local subgroup called Nganawirdbird demonstrates:

The principal Dreaming of the Nganawirdbird group is Garawi, or plains kangaroo. This is a major Dreaming of the claim area. Its track enters the claim area from the 
direction of Mataranka. The first site visited by the Dreaming on the claim area is Gorowan, on Salt Creek. The Dreaming then visited Na-Burl (Elsey Falls), Murrwale and Barlmarrag, all on the Roper River. Between Murrwale and Barlmarrag is a waterhole, into which the Garawi jumped and in which it submerged. It travelled underground to the north and re-emerged at Nganawirdbird. This is a place of great significance. It consists of a large sinkhole and limestone cave at the top of a hill.

(Commonwealth of Australia, 1990, p. 107)

The stories of these ancestral creatures, and indeed the creatures themselves, form the substance of the landscape and so survival of the land and waters, of the Dreaming beings, and of the stories are all interrelated, as local elder, S.C., made clear in a public meeting with water agency staff.

That Dreaming track, give it back, that land! It's Whirlwind Dreaming. The spring has been damaged around Mataranka. The story could end up drying up when the spring dries up (Field notes, 16/05/2010).

The Dreaming creators (known as Warrwiyan in the Mangarrayi language) formed the country, but also populated it with living creatures such as people, animals and plants, provided language and laws to live by, and continue to dwell in the landscape. Human beings must negotiate with such powers, requiring key individuals to have particular kinds of knowledge and to follow the rules associated with particular places, as explained by S.C.:

S.C.: ... That's my country. That's rain Dreaming. Garnan. Warrwiyan.

M.B.: So that's a Warrwiyan area too? 
S.C.: Yo eh! One big ridge go down. Down the river, and that high hill, and one go up like that, high bank.

M.B.: Are there rules about that place?

S.C.: Yeah! Jayway! Jayway.

M.B.: Rainmaker? Someone who knows how to do it, make it rain?

S.C.: Yes. Rain. You got to throw all the stone, and rain coming

Merlan notes that the Mangarrayi pride themselves on their association with the riverine country along the Roper and other bodies of water within their country' (1982, p.146) and people interviewed for this research made a range of statements about the value and importance of water, reflecting both its cosmological and ancestral significance as well as its importance in everyday life. Researchers elsewhere report indigenous people frequently describing water as an element that embodies a life force, that is 'living water' (Rose, 2004; Toussaint et al., 2005; Yu, 2000). The role of water in embodying and sustaining life is evident from similar comments made in the Roper:

Water is life, gives life to the land. It feeds the environment, keeps country cool and healthy. We don't like to damage country. It's good for fishing, swimming, camping. We use it for teaching too - cultural stories, bedtime stories, camping beside the river. It's our heritage. We need it to visit, enjoy life.

M.H.

Water is needed for the animals and the sacred areas. Water for the country and the people. 
Within these expressions lie implicit values about how water should be shared amongst all life forms and how, through that sharing, all life is interconnected. The capacity for water to connect and unify human beings, as well as to define boundaries between them, is the subject of the next section.

\section{Water as a unifier and identifier}

Water is conceptualised and used by indigenous people as a way of creating relationships, connections, and boundaries (Barber and Jackson, 2011b; Jackson, 2006; Langton, 2004; Weir, 2009). Much like the movement of water, this is a dynamic and ongoing process, but also one that follows regular and predictable paths. Signs of connection in the landscape can be used to understand and re-interpret social relationships, as the two are understood to go together. Recent discussions of groundwater flows for the purposes of water planning (spatial extent, rates and points of recharge and discharge to the surface) reveal the continuous nature of these reinterpretations:

The water goes up and curls back down again, moving through the different countries.

We are connected through that water.

\section{A.M.}

When we talk about water we are all together, we are all for the water. It starts from there, and we still connect for the water. That's what we'll be talking about, from the top to the bottom, as far as the water goes down.

R.S. 
We [Wubaluwun people] are upstream, we are the point of origin. We are guardians for the downstream people and they are the guardians for us. The Elsey mob are getting us involved because we are upstream. They've got the underground water for us, and we've got the surface water for them. The ownership of the two goes hand in hand.

A.M.

As well as connecting peoples, water can also be used to create boundaries between them. Salt Creek for example is generally referred to as the marker of the boundary between Mangarrayi and Yangman territory (Commonwealth of Australia, 1997). The nature of individual identities means that people may be strongly connected to adjoining groups or territories, but these boundaries are nevertheless respected and recognised as important in certain contexts:

We are connected to each other through the water flow, we make those decisions together. But I would not speak for someone else's country, and they should not speak for mine. What is needed is agreement between the top and the bottom stream.

A.M.

The rules about speaking for particular places are part of a wider set of protocols to follow and responsibilities to fulfil as part of people conducting themselves appropriately with respect to each other, the ancestral powers in the landscape, and the country itself. This aspect will be the focus of the next section. 
Water ethics and reciprocal responsibilities

Regular human presence at important places is a key aspect of their ongoing viability, especially the presence of those who know the stories, who are known by that place, and who have been trained in how to behave properly. The literature pertaining to the Roper region contains evidence of a range of practices and protocols with respect to water and the wider landscape. These 'ethical practices of care' for water (Rose, 2004, p.35) have been described elsewhere in relationships between indigenous people and water in other Australian regions (Toussaint et al., 2005). For instance, in their study of the Katherine area in the adjacent Daly River catchment, Cooper and Jackson (2008) identify a range of important protocols and practices governing cultural water sites and landscapes. These include talking to country, 'watering' strangers and others who have been away from the area for long periods, behavioural restrictions, and obligations to protect visitors and sites from harm. The authors note that these practices flow from the belief in ongoing spiritual presence in the landscape of both the original Dreaming beings and the more recent remembered and unremembered ancestors.

The research conducted here revealed a range of similar responsibilities and protocols with respect to country and the wider landscape. Changes in lifestyles have altered some protocols over time, but such conditions on conduct are nevertheless known and followed by people in a range of situations. They are taken as important indications of the operation of a system of law and appropriate conduct in water management. As was indicated above, they include the right to speak about the country, but are not limited to it:

We are worrying about that spring. Kangaroo Dreaming story around the mango farm. Mataranka families are responsible for that one. We need them to look after that place. 
S.C.

On Jawoyn country they have to put water over new arrivals, call out to the spirits and the ancestors so they don't get sick. That's my father's father's country. We don't do that with Yangman country, but we do call out to the old people to give us some fish. You have to do it the right way.

S.R.

The changes necessitated by colonisation have affected the extent to which such protocols can be and are followed, and Merlan describes how changes to settlement patterns have reduced visitation to key places, in turn affecting knowledge of protocols and practices:

During a visit to Lududmini (Crescent Lagoon, Elsey Station), an important `sickness place' and also a rainmaking site, the Mangarrayi were describing the now-lapsed practices of the jayway, the 'rainmakers' of the descent group which owns the area. One of the present owners of Lududmini remarked, 'I don't know how we get rain today. Must be we're just bludging the white man's rain' (1978, p. 75).

However, even if the details of particular practices have been lost, a strong sense of obligation and responsibility remains, manifested in clear priorities about how water sharing should be conducted in the context of $21^{\text {st }}$ century commercial activity:

Water for the country comes first. People need water too, for fishing and hunting. That's the most important one.

M.M. 
'Water for the country' is a phrase intended to encompass water in the springs, rivers, creeks and waterholes, water at important Dreaming places, water for plants and animals, and water sufficient to maintain ongoing subsistence. In other words, the priority is on water which supports all life. The sense of responsibility that M.M. articulates is an aspect of a wider sense of custodianship and guardianship, and this in turn implies a sense of ownership with respect to non-Aboriginal people which is the subject of the next section.

\section{Water ownership, entitlement, and rights}

The ongoing sense of obligation people feel with respect to looking after the country is an expression of guardianship and responsibility and is related to a form of traditional ownership. The separation of water and land rights characteristic of wider Australian tenure regimes does not exist in indigenous societies, which conceive of water and land as an interrelated and indissoluble whole - country. Further comments about water and its availability reflect this conception of responsible ownership, of people asserting their rights as owners of both water and land, but also reflecting on the obligations that come with those rights - obligations to look after and respect others present on the country.

The country needs water. We respect the farmers for growing the food we eat and we can share with them, but we have to look after the country as well.

\section{K.M.}

We pay rent for water to our houses. Why do we do that? They should be paying us for that water.

\section{A.M.}


If they want to establish a farm, they should ask the people first. If it is on their land, then they should pay.

J.M.

It's ok to do a bore to make a business, but the water must keep running on the river.

F.R.

The range of comments here reflect assertions of ownership, concern to accommodate competing interests, willingness to negotiate, criticism of processes that have not respected them as owners, concern for matters that may not have been properly considered, and an underlying need to protect the country. Water and land are taken as an indissoluble whole, and local attitudes to management reflect that assumption. Those interviewed see their role as not just guardians of country, but as potential beneficiaries of productive activities that take place there. Discussions of water allocations for commercial purposes are therefore of primary interest to people who regard themselves as the owners of that water. That these people are also economically marginalised and are searching for opportunities to mitigate that marginalisation only increases their desire for appropriate recognition. However before examining the contemporary planning context through which traditional owners are seeking such recognition, one further feature of the Roper situation will be discussed, and this is a distinctive example of the importance of water to the wider landscape, beyond the river course.

Riparian landscapes - the personification of trees

In analysing the engagements between people and places along the upper Roper, Merlan (1982) noted a distinction in the use of the term Warrwiyan that she believed unusual in the 
literature. She identified its use to describe the Dreaming beings, but also to describe particular features in the landscape (notably large trees, often found adjacent to important water sites.) These trees represented and embodied distinct individuals from current or recent previous generations and in this sense the landscape alongside the water course was 'personalised' by trees which were 'signs of the presence and activities of the creative forces' (Merlan, 1982, p.149). Cooper and Jackson (2008) describe regularly recurring associations between riparian vegetation and Dreamings across different regions of Australia, but these are significant as either transformations of ancestral beings or as resources used and left by them. Merlan (1982) however describes how trees along the Roper River are identified directly with living or relatively recently deceased people, who may belong to different patrilineal lineages but the same kinship category (known as a semimoiety) as the country. This system relates living people to both the lines of descent and to the totemic creatures who created the land. Trees, particularly large ones, retain their cultural significance today and the practice of associating with a particular person through naming has continued across generations, as one informant stated:

Trees do have the name. Name of that person. The ones which grow in special places. When we see the Dreaming tree, we know not to touch that. Don't put a fence line through there, put it around it.

R.R.

The distinctive personal character ascribed to large trees adjacent to significant water bodies is a useful example of the need for water to be considered as part of a wider landscape, not as an isolated resource. Clearly water plans cannot encompass the full range of landscape management issues and remain targeted, coherent, and useable. Yet the additional 
significance of riparian vegetation in this context emphasises the need for integrated management structures. The next section examines the local water planning context in greater detail.

\section{The Upper Roper River Water Plan}

\section{Plan contents and context}

The draft Mataranka (Tindal Aquifer) Water Allocation Plan, hereafter referred to as the Plan, was developed from 2009-2011 and released for public comment in November 2011 (www.nretas.gov.au). The stated purpose of the Plan is to provide the Northern Territory water agency and the Mataranka community with a transparent set of rules that will assist in the sustainable management and equitable allocation of water within the limestone aquifer (DNRETAS, 2011). It recognises the public and private benefits gained from groundwater and makes provision to protect groundwater dependent ecosystems by ensuring that the majority of the annual recharge remains in the environment. One of the Plan's key aims is to enable the 'development of agriculture, sustainable commercial tourism, and other water consumptive industries that form a significant part of the Mataranka region' (DNRETAS, 2011, p. 10) and to that end, the plan allocates water within the estimated sustainable yield to those uses.

Consistent with national standards of water plan development, Northern Territory water law establishes stakeholder advisory committees comprised of representatives from key stakeholder groups to provide the community with opportunities to be involved in developing water allocation plans and at a range of levels. A Water Advisory Committee for the upper Roper was formed during the planning process and included representatives from the pastoral, mining, horticulture, community conservation, and national parks sectors, as well as 
an independent chair. The one indigenous representative was not a traditional owner from any of the interested groups, but rather was the former manager of the now indigenous-owned Elsey Station. In recognition of the serious limitations of the stakeholder model of representation for effective indigenous participation (Jackson et al., 2012), local indigenous organisations established a separate reference group of traditional owners from the area to provide further input on water planning and allocation, known as the Mataranka Traditional Owner Water Allocation Reference Group (see http://nailsma.org.au/hub/media/pressrelease/media-release-traditional-owners-speak-out-mataranka-water-allocation-plan). The group was made up of representatives from several language and/or territorial groups affected by the Plan.

The Plan recognises the deep spiritual affiliation that traditional owners have with the many springs, soaks, billabongs, streams, creeks and rivers associated with the aquifer and the large proportion of indigenous land in the plan area. It assumes that provision of recharge for environmental protection will maintain the condition of places that are valued by indigenous people for cultural purposes, although it acknowledges that 'cultural requirements may not align with environmental water requirements' (DNRETAS, 2011, p.5). A comprehensive study of indigenous interests or water requirements was not undertaken prior to plan development, although in the draft plan reference was made to the independent study conducted by the authors then underway but not complete (Barber and Jackson, 2011a).

Of the Plan's four proposed outcomes, one is directly targeted at enhancing the benefits to indigenous people:

Maintenance and support for traditional land use in the predominately Indigenous owned land surrounding the Mataranka Water Planning Area through the protection of 
culturally significant water dependent sites as well as providing access to water for commercial development (DNRETAS, 2011, p. 11).

This outcome is to be achieved with two strategies. Firstly, the water controller will set aside water for 'indigenous commercial development' (DNRETAS, 2011, p. 11). Secondly, the Department will continue partnerships with research organisations to improve knowledge of 'cultural water requirements' (Part 6 Clause 29). To that end, a report identifying indigenous water related cultural values is to be produced during the life of the Plan and a methodology to quantify water requirements for indigenous cultural purposes is to be developed.

\section{The Strategic Indigenous Reserve (SIR): a commercial allocation}

Current Northern Territory water law does not recognise the need for an indigenous specific allocation for commercial purposes. Sustained lobbying by indigenous organisations in the NT and beyond during the past three years has resulted in a significant Australian water policy innovation, the SIR, which is designed to provide economic benefits to indigenous people from the use of and trade in water (Nikolakis, 2011). An SIR was first proposed in 2009 in the Katherine (Tindal Aquifer) Water Allocation Plan which applies to the same aquifer and the land area immediately north of the Mataranka Plan (DNRETAS, 2009b). The Katherine Plan (2009-2019) mandates 680 mega litres (ML) for indigenous commercial development if the existence of native title is recognised within five years of plan commencement. This amount of water was determined by the percentage of the plan area under native title claim in 2009 - some 2 per cent approximately. For as long as the native title determination is unresolved, there remains no indigenous specific allocation.

The Mataranka Plan proposes to substantially amplify the scale and significance of the SIR. The amount specified in the draft Plan is (4 $875 \mathrm{ML} /$ year), or $25 \%$ of the commercial 
allocation (Part 5 Clause 20, DNRETAS 2011). In the form contemplated in the Mataranka Plan, the reserve could be accessible by the grant of licenses (entitlements) that are saleable as a temporary trade. The rules surrounding the issue of water licences for that part of the licence pool designated as a SIR have not yet been developed but will be documented in the implementation strategy for the Plan. As Jackson and Langton (2012) and O’Donnell (2011) argue, the existence of an SIR can overcome two barriers to justice in the Australia system of water allocation. Firstly, as 'late entrants' to a water market with economic aspirations that are still taking shape, indigenous people could be assured of access to water for commercial purposes. Secondly, the reserve also allows those 'indigenous people without land rights or native title guaranteed access to water for development purposes' (O'Donnell, 2011, p. 237).

Despite the substantial progress it represents from the Katherine plan (and the significant departure from other Australian allocation plans that make no such provision for indigenous access to water), during the course of the research in the Roper, the magnitude of the proposed Mataranka SIR was regularly raised by indigenous research participants as a significant concern. A crucial context for that concern is that compared with the Katherine plan area, indigenous people form a much larger proportion of the resident population of the upper Roper River and are major landowners in the area. Local indigenous people's awareness of these facts strengthened the generalised sense of entitlement to water allocations in the Mataranka plan based on their understanding of their position as owners of the 'country' as a whole. As a consequence, a reserve of $25 \%$ was seen as inadequate rather than the substantial step forwards it represents compared with water plans generated elsewhere: 
We are not asking for all the water. But the consultation process was wrong and so we did not get the chance to negotiate. Being the majority landholders, I felt we had that right.

A.M.

$25 \%$ or $30 \%$ from the government is not enough, they have kept more water than we have.

R.B.

That water should be 50:50 split, between indigenous and government. People can have the water from us if they want it. We will give the permit.

R.S.

Despite local indigenous reservations, the $25 \%$ allocation represents an order of magnitude increase on the small and highly conditional SIR which was the innovation in the Katherine plan. Wider discussions involving a range of organisations and indigenous groups about the SIR issue are ongoing and representative groups have called for the Plan to be reviewed every two years to allow traditional owners to 'have a proper say on the Plan, including the SIR' (NAILSMA, 2011). Some doubt has been recently cast over the future of this innovative policy mechanism as a result of a change of government in the Northern Territory in late 2012. In March 2013, the new conservative government announced that it would defer the establishment of the SIR for three years although the draft plan had not been amended at the time of writing. Such developments indicate both the potential level of ongoing contestation about water and the corresponding political risks faced by indigenous people in trying to gain a share of the resource, even a share they themselves believe to be inadequate. 


\section{Discussion and Conclusion}

The significance of water for indigenous people from the Roper catchment encompasses mythology, social identity, ethical conduct, and ownership, as well as the interrelationships between these different valuations. Local norms relating to resource ownership, use and distribution emphasise that water is valued as a 'resource', but this by no means exhausts indigenous perspectives on the issue. Indigenous members of the community also call for parity of representation in decisions affecting water use and management. It is therefore important that an assessment of progress towards social justice examines the extent to which the socio-economic conditions of the affected community are improved, recognition of cultural difference and identity are enhanced and all members of the political community are given equal voice in public deliberations. As per Fraser's theorisation (2009), planning needs to simultaneously attend to the socio-economic, cultural and political dimensions of water justice.

The water planning goals of environmental protection of groundwater dependent ecosystems, indigenous cultural recognition, and sustainable development accord with contemporary indigenous perspectives, whilst the increase in size and the removal of any proof of native title precondition on the SIR in the Mataranka plan means it represents a substantial improvement on the Katherine Plan. In the Northern Territory at least, there are now real prospects for indigenous people to benefit from the expansion of commercial activities reliant on water. However, despite these successes, there remain important limitations in the engagements between indigenous water values and interests and contemporary water planning. These are discussed in more detail below. 
The first limitation has just been noted, namely that the substantial and welcome increase in the potential size of an SIR allocation is nevertheless perceived as inadequate and unsuited to local conditions and has now been deferred. This raises the wider point of the degree to which water plans and policy instruments that apportion water to users are able to appropriately accommodate widely varying tenure regimes, population levels, and community aspirations. Although it correlates with percentages raised in indigenous policy discussions and forums (NAILSMA/IWPG), the proposed 25\% figure is nevertheless an arbitrary one and this invites criticism on both sides - that it is not large enough, or that it is too large. Assuming SIRs are implemented in other plans within the NT and beyond, policy makers will need to establish robust and transparent ways determining appropriate allocations. Such methods will also need to be flexible enough to address hydrological and climatic variation in the regions subject to water sharing.

The second limitation relates to the scale and boundedness of the demarcated area. In Mangarrayi relationships to water we can see that Dreamings connect people and places from the plan area (referred to in statute as the Water Control District) to people and places beyond it. The Roper River is a focal zone for Dreaming connections, but Dreamings and the waters associated with them can connect and be connected across wide areas (as far as the coast in the Gulf of Carpentaria, 250 kilometres east). Further, traditional owners from the region reside in communities of place located outside the plan area. A plan's spatial extent is determined by the size of a particular water resource, such as part of an aquifer, and where specific management rules are required (DNRETAS, 2011a). In this case, the boundary for plan is based on that part of the Tindal aquifer in the Mataranka area which flows towards, and has direct effects on, the groundwater-dependent ecosystems in and around the Elsey 
National Park (see Figure 1). Just as water management is now attuned to ecological boundaries such as catchments, planners will need to pay attention to the cultural logic of plan boundaries and incorporate interests and perspectives that extend beyond the jurisdictional scale of the plan.

The third limitation relates to the scope of water plans. The environmental features of most importance in the context of the plan are currently considered to be the ground water dependent ecosystem such as springs, the Mataranka thermal pools and the Roper River itself. Yet taking seriously the 'personalised' character of the riparian landscape and waterways of Mangarrayi country requires that many other features of the landscape beyond the water bodies need to be considered. The varied creative acts of the Dreaming ancestors generate a wide variety of valuable features in the landscape, and in the Roper case, the particular significance given by local indigenous people to large riparian trees suggests that they too need to come directly within the scope of the plan. The holism of indigenous environmental perspectives generates challenges for their appropriate inclusion in water planning processes which are conceptually and procedurally constrained.

A fourth limitation relates to the articulation between local indigenous resource governance structures and the broader structures generated by water planning processes. The additional value of mature riparian vegetation in the planning area suggests the need for additional monitoring and management activities, as well as the need to involve local indigenous people in that effort. Such involvement would generate confidence in its utility and appropriateness, but the structures by which that effort should be managed and the relationship of any new effort to existing local indigenous NRM management efforts (such as those undertaken by the Mangarrayi Rangers, see Barber and Jackson, 2011a) may require careful consideration. The 
existing indigenous advisory structure established as part of the water plan contains representatives from groups across the entire planning area. Whilst appropriate at the catchment scale, such a body is not necessarily the most appropriate place for determining management actions on the estates of one or more of its constituent members. This is a specific example of the question of scale, but also a matter of appropriate governance.

The question of governance and of the articulation with indigenous customary management of country raises an additional limitation. Although water plans are increasingly effective at acknowledging indigenous water values and interests, there is a need to resource indigenous capacity to undertake ongoing land and water management. This issue is particularly significant for the Roper, where a new indigenous governance body has been established to manage a significant commercial water allocation, and where the primary indigenous NRM organisation, the Mangarrayi Rangers, is only a few years old and is relatively small compared with many groups of its kind elsewhere.

Lastly, there is the deeper underlying limitation regarding the degree to which a resource allocation process modelled on the comprehensive-rational approach to planning can genuinely account for alternative cultural perspectives. Water plans are expected to incorporate indigenous social, spiritual and customary objectives and strategies for achieving these objectives wherever they can be developed (Australian Government, 2004), according to the NWI, to which the NT Government is a signatory. Yet it appears from the Roper experience that it may well be easier for the western resource management paradigm to accept reforms that result in economic or redistributive outcomes for indigenous people than it is to recognise the dominance of western cosmological models and therefore the lack of cultural recognition in water planning. In the Roper River process, the expressed aspiration 
to quantify an allocation for 'cultural values', for example, suggests that the rationalist, reductionist mode of planning remains unable to effectively acknowledge different world views relating to nature, intangible environmental qualities, and human relationships with rivers and water bodies that are not readily amenable to quantification (Jackson, 2006).

For over twenty years there have been calls for planners to recognise and accommodate difference in environmental valuations (Beauregard, 1991; Sandercock, 1996; Richardson, 2007) and, in response, increased attention has been given by planning theorists to culture, community and place, as well as to communication and planning process (Healey, 1993). In the Australian literature, authors have particularly noted the negative effects that assumptions of cultural homogeneity have had on indigenous peoples in a range of planning contexts (Jackson, 2006; Lane, Brown and Chase 1997; Davies and Young, 1996).

Yet the Roper experience suggests that the shortcomings raised in the literature are not universally accepted by practitioners and that the ways in which a plan frames and acts upon the interests of indigenous people are still very limiting, particularly with respect to addressing their highly integrated cosmological models (Strang, 2007) and expectations for equitable participation (Jackson et al. 2012). Like many of its kind, the rationalist water plan embeds a separation between 'nature' and 'culture' which is pervasive and largely transparent in contemporary western conceptions of land and waterscapes (Healey, 2007). For example, the plan aims to protect the 'natural assets' of the Mataranka area (DNRETAS, 2009a) and these are primarily the popular environmental features of value to residents, including the indigenous community, tourists and the wider public - the springs, thermal pools and Roper River channel. This aim is a common over-arching objective in contemporary approaches to 
environmental management in Australia where 'water' is conceptualised as a 'resource' or 'asset' to be managed in technical terms.

The landscape qualities so important to indigenous people, as well as their socio-cultural context such as religious systems, may be perceived as intangible, subjective and outside the realm of water management agencies' legislated responsibilities to manage the water resource (Finn and Jackson, 2011). The plan sits within a wider environmental management discourse that narrowly defines its jurisdiction to the management of 'natural' objects and processes and in doing so entrenches the dualism that frames nature as a 'kind of technical ecology' (Strang, 2009: 2). In this case, attending to the social implications of changes in land and water use is likely to be considered out of bounds for the planner who is charged with responsibilities only for water and whose powers are limited to influencing river discharge (via water licensing and allocation). For indigenous peoples, however, water eludes this type of classification and, as the above results show, water is a very different entity altogether. There is a profound conceptual challenge represented by this ontological and cosmological difference.

Recent developments in the Northern Territory demonstrate that water planners and indigenous water managers are seeking solutions to the long standing neglect of indigenous water rights by the Australian state. According to many indigenous advocates, the denial of commercial water rights represents a fundamental shortcoming in Australian water policy (Lingiari Foundation, 2002; McAvoy, 2005). Therefore the creation of an SIR in two NT water plans (one still in draft) should be recognised as a significant step towards redistributive water justice in Australia. Indeed, a pan-north Australian non-government organisation, the Indigenous Water Policy Group, believes that SIRs are a means of 
'enhancing the recognition of Indigenous water rights and for transforming that recognition into practical outcomes that will contribute to the overall well-being of Indigenous communities' (NAILSMA 2013, p. 1). Nonetheless, local expressions of dissatisfaction with the magnitude of this potentially valuable allocation in the Roper case at least, suggests that resolution of inter-cultural contestations over water governance will not come easily. Jurisdictions might need to consider negotiating a consistently applied basis for defining an equitable share with indigenous representative organisations if they are to avoid ad hoc and arbitrary decision-making.

The above limitations suggestchallenges for the planning system in resolving Fraser's 'redistributive - recognition dilemma' (1995). Some steps have been made to remedy injustice through economic restructuring by allocating entitlements to indigenous people, but the planning systems described here are not yet able to adequately attend to the symbolic and spiritual realms of indigenous life. Claims for recognition complicate redistributive struggles and so water management practices like allocation planning and hydrological assessment need to allow for the actualization of complex and distinct indigenous values if they are to avoid escalating conflict over resource management decisions. This requires a move from token acknowledgement to the appropriate resourcing of long-term processes that maintain, affirm, and, in some cases, restore and enhance, indigenous relationships with water and water bodies..

Indigenous participation in long-term monitoring of allocation decisions could provide additional opportunities for affirming political representation and cultural recognition. Similarly, indigenous participation in data collection and processes of exchange and learning across cultures should be encouraged to inform and adapt management actions. Applying both indigenous and research-based knowledge to a contemporary management problem will 
affirm the importance of indigenous perspectives and epistemologies. It might also provide a forum through which tacit indigenous ecological knowledge and underpinning beliefs and values, such as water's creative potential, its unifying capacity and its role in the ethics of care, are passed on to younger generations.

Fraser attempts to 'figure out how to conceptualize cultural recognition and social equality in forms that support rather than undermine one another' $(1995$, p. 69) and to advance claims for parity of participation in the procedures for 'staging and resolving contests in both the cultural and economic dimensions' (2009, p. 17). The Roper case would appear to show how challenging such a task is for conventional planning, even in a situation where indigenous groups are both numerically dominant and the largest landowners, suggesting strong economic bargaining power. Breaking the binds between economic disadvantage, cultural disrespect and misrepresentation will indeed be hard in a settler society such as Australia, where land management institutions that have their origins in processes of indigenous dispossession, disenfranchisement and eradication of cultural difference. The question is whether, as Fraser (2009) argues, a reframing of political representation would assist in further addressing maldistribution and misrecognition, and what form such a reframing should take?

The standard model of stakeholder representation initially failed to provide adequate opportunity for indigenous participation in water allocation. A Mataranka Water Advisory Committee with an indigenous membership that reflected demographic and land tenure realities would seem likely to have not only suggested a different quantum of water than the one currently proposed for indigenous commercial benefit, but have taken a much broader perspective regarding its legitimacy and its role in understanding and managing water 
resources into the future. The separately and formally constituted indigenous water reference group (MTOWAR) seems a significant step forward, but it nevertheless faces its own challenges with respect to representation and articulation with both landowning groups and indigenous managers on the one hand, and wider stakeholder water advisory processes on the other. The Roper case represents a current 'high water mark' in allocation outcomes, yet also points to the need for substantial reform and revisioning of future processes in this and similar contexts to attain the kind of economic, cultural and political justice to which Fraser's threefold argument aspires. 


\section{References}

Altman, J. (2004) Indigenous interests and water property rights, Dialogue, 23, pp. 29-43.

Altman, J., Buchanan, G. \& Larsen, L. (2007) The environmental significance of the indigenous estate: natural resource management as economic development in remote Australia, (Canberra, Centre for Aboriginal Economic Policy Research Discussion Paper No 286/2007, Australian National University).

Altman, J. \& Branchut V. (2008) Freshwater in the Maningrida region's hybrid economy: intercultural contestation over values and property rights. (Canberra, Centre for Aboriginal Economic Policy Research, Australian National University).

Australian Government (2004) The National Water Initiative Inter-Governmental Agreement. (Canberra, Commonwealth of Australia).

Barber, M. (2005) Where the clouds stand: Australian Aboriginal attachments to water, place, and the marine environment in Northeast Arnhem land (Canberra, Department of Anthropology, Australian National University PhD Thesis).

Barber, K. \& Rumley, H. (2003) Gunanurang (Kununurra) Big River, Aboriginal Cultural Values Of The Ord River And Wetlands. (Perth, Western Australian Water and Rivers Commission).

Barber, M. \& Jackson, S. (2012) Water management and the mining sector: the intersection of Corporate Social Responsibility in Indigenous engagement and corporate leadership in catchment management, Resources Policy, 37(2), pp. 48-52.

Barber, M. \& Jackson, S. (2011a) Indigenous water values and water planning in the Upper Roper River, Northern Territory, CSIRO, Darwin. 
Barber, M. \& Jackson, S. (2011b) Indigenous people, water values and resource development pressures in the Pilbara region of north-west Australia, Australian Aboriginal Studies, 2, pp. 32-49.

Behrendt, J. \& Thompson, P. (2004) The recognition and protection of Aboriginal and interests in New South Wales rivers, Journal of Indigenous Policy, 3, pp. 37-140.

Beauregard, R. (1991). Without a net: modernist planning and the postmodern abyss, Journal of Planning Education and Research, 10(3), pp. 184-94.

Bruns, B., Ringler, C., \& Meinzen-Dick, R. (2005) Reforming water rights: Governance, tenure and transfers, in: B. Bruns \& R. Meinzen-Dick (Eds) Negotiating water rights, pp. 284-309 (London, Intermediate Technology).

Burchi, S. (2005) The interface between customary and statutory water rights - a statutory perspective. International Workshop on African Water Laws: Plural Legislative Frameworks for Rural Water Management in Africa (Johannesburg, 26-28 January 2005).

Cranney, K. \& Tan, P. (2011) Old knowledge in freshwater: Traditional ecological knowledge in the Mitchell catchment, Australasian Journal of Natural Resources Law and Policy, 14(2), pp. $71-113$.

Commonwealth of Australia (1990) Mataranka Area Land Claim, Report No. 29. Report by the Aboriginal Land Commissioner, Mr Justice Maurice, to the Minister for Aboriginal Affairs and to the Administrator of the Northern Territory. Australian Government Publishing Service, Canberra.

Commonwealth of Australia (1997) Elsey Land Claim No. 132. Report and recommendation of the Aboriginal Land Commissioner, Justice Gray, to the Minister for Aboriginal and 
Torres Strait Islander Affairs and to the Administrator of the Northern Territory. Aboriginal and Torres Strait Islander Commission, Canberra.

Connell, D., Dovers, S. \& Grafton, R. (2005) A critical analysis of the National Water Initiative, Australasian Journal of Natural Resources Law and Policy, 10, pp. 81-107.

Cooper, D. \& Jackson, S. (2008) Preliminary study on Indigenous water values and interests in the Katherine region of the Northern Territory, Report to the North Australian land \& Sea Management Alliance's Indigenous Water Policy Group (Darwin, CSIRO). $<$ http://www.terc.csiro.au/resources\%5CKatherine\%20Indigenous\%20Water\%20 ValuesApril08.pdf> (accessed 10 February 2012).

Davies, J. \& Young, E. (1996) 'Taking centre stage': Aboriginal strategies for redressing marginalization, in: Howitt, R., J. Connell \& P. Hirsch (Eds) Resources, Nations and Indigenous Peoples, pp. 152-71 (Melbourne, Oxford University Press).

Department of Natural Resources, Environment, The Arts and Sport (DNRETAS) (2009a) NRETAS Situation Analysis: Mataranka Water Allocation Plan June 2009 (Darwin, Department of Natural Resources, Environment, The Arts and Sport).

Department of Natural Resources, Environment, The Arts and Sport (DNRETAS) (2009b) Water Allocation Plan for the Tindal Limestone Aquifer, Katherine 2009-2019, (Darwin, Department of Natural Resources, Environment, The Arts and Sport). <http://www.nt.gov.au/nreta/water/kwac/wap.html> (accessed 8 December 2011).

Department of Natural Resources, Environment, The Arts and Sport (DNRETAS) (2011) Water Allocation Plan for the Tindal Limestone Aquifer, Mataranka, (Darwin, Department of Natural Resources, Environment, The Arts and Sport). < http://www.nretas.nt.gov.au/_data/assets/pdf_file/0017/118070/Draft-WaterAllocation-Plan-Tindall.pdf>, accessed 15 January 2012. 
Finn, M. \& Jackson, S. (2011) Protecting Indigenous values in water management: a challenge to conventional environmental flow assessments, Ecosystems, 14(8), pp. $1232-1248$.

First Peoples Water Engagement Council (2012) Advice to the National Water Commission, May 2012, < http://nwc.gov.au/_data/assets/pdf_file/0004/22576/FPWEC-Advice-toNWC-May-2012.pdf> (accessed 3 June 2012).

Fraser, N. (1995) From redistribution to recognition? Dilemmas of justice in a 'post-socialist' age, New Left Review, 212, pp. 68-93.

Fraser, N. (2009) Scales of Justice: Reimagining Political Space in a Globalizing World (New York, Columbia University Press).

Godden, L. \& Foerster, A. (2012) Introduction: Institutional transitions and water law governance, The Journal of Water Law, 22, pp. 53-57.

Gunn, J. (2003) [1908] We of the Never-Never. Project Gutenberg.

Healey, P. (1993) Planning through debate: the communicative turn in planning theory, in: F. Fischer \& J. Forester (Eds) The Argumentative Turn In Policy Analysis And Planning, pp. 233-253 (Durham and London, Duke University Press).

Healey, S. (2007) Deadly Dingoes: 'Wild' or Simply Requiring 'Due Process'?, Social Studies of Science, 37(3), pp. 443-471.

Hussey, K. \& Dovers, S. (2007) Managing Water for Australia: the Social and Institutional Challenges (Melbourne, CSIRO Publishing).

Jackson, S. (2005) Indigenous values and water resource management: A case study from the Northern Territory, Australasian Journal of Environmental Management, 12(3), pp. 136-146. 
Jackson, S. (2006) Compartmentalising culture: The articulation and consideration of Indigenous values in water resource management, Australian Geographer, 37(1), pp. 19-32.

Jackson, S. (2011) Aboriginal access to water in Australia: Opportunities and constraints, in: Q. Grafton \& K. Hussey (Eds) Water Resources, Planning and Management, pp. 601-628 (Cambridge, Cambridge University Press).

Jackson, S. \& Langton, M. (2012) Trends in the recognition of indigenous water needs in Australian water reform: the limitations of 'cultural' entitlements in achieving water equity, Journal of Water Law, 22(2/3), pp.109-123.

Jackson, S., Tan., P, Mooney, C., Hoverman, S. \& White. I. (2012) Principles and guidelines for good practice in Indigenous engagement in water planning, Journal of Hydrology, 474, pp. 57-65.

Jackson, S. \& Altman, J. (2009) Indigenous rights and water policy: perspectives from tropical northern Australia, Australian Indigenous Law Review, 13(1), pp. 27-48.

Jackson, S., Tan, P, Mooney, C., Hoverman, S. \& White, I. (2012) Principles and guidelines for good practice in Indigenous engagement in water planning, Journal of Hydrology, 474, pp. 57-65.

Jackson, S. \& Langton, M. (2012) Trends in the recognition of indigenous water needs in Australian water reform: the limitations of 'cultural' entitlements in achieving water equity, Journal of Water Law, 22, pp. 109-123.

Lake, R. (1996) Volunteers, NIMBYs, and environmental justice: dilemmas of democratic practice, Antipode, 28(2), pp. 160-74. 
Lane, M., Brown, A. \& Chase, A. (1997) Land and resource planning under native title: towards an initial model, Environmental and Planning Law Journal, 14(4), pp. 249-58. Langton, M. (2002). Freshwater. Background briefing papers: Indigenous rights to waters, pp. 43-64 (Broome, Lingiari Foundation).

Langton, M. (2006) Earth, wind, fire and water: the social and spiritual construction of water in Aboriginal societies, in: D. Bruno, B. Barker \& I. McNiven (Eds) The Social Archaeology of Australian Indigenous Landscapes, pp. 139-160 (Canberra, Aboriginal Studies Press).

Lingiari Foundation (2002) Onshore water rights. A discussion booklet for the Aboriginal and Torres Strait Islander Commission (Broome, Lingiari Foundation).

MacAvoy, T. (2006) Water - Fluid Perceptions, Transforming Cultures eJournal, 1(2), pp. 97-103.

McFarlane, B. (2004) The National Water Initiative and acknowledging Indigenous interests in planning, Paper presented to the National Water Conference (Sydney, 29 November 2004).

McGrath, A. (1987) Born in the cattle (Sydney, Allen and Unwin).

Merlan, F. (1978) 'Making people quiet' in the pastoral north: reminiscences of Elsey station, Aboriginal History, 2(1), pp. 70-106.

Merlan, F. (1981) Land, language, and social identity in Aboriginal Australia, Mankind 13(2), pp. $133-148$.

Merlan, F. (1982) A Mangarrayi representational system: environment and cultural symbolisation in Northern Australia, American Ethnologist, 9(1), pp. 145-166.

Merlan, F. (1986). Mataranka land claim: senior anthropologist's report on behalf of the claimants (Darwin, Northern Land Council). 
Merlan, F. (1987) Catfish and alligator: totemic songs of the western Roper River, Northern Territory, in: M. Clunies-Ross, T. Donaldson and S. Wild (Eds) Songs of Aboriginal Australia, pp. 142-167 (Sydney, University of Sydney).

Merlan, F. (1993) Elsey Land Claim No. 132 Anthropologist's report (a supplement to the Mataranka land claim book (Darwin, Northern Land Council).

Merlan, F. (1996) Big river country: stories from Elsey Station (Alice Springs, IAD Press).

Mooney, C. \& Tan, P. (2012) South Australia's River Murray: social and cultural values in water planning, Journal of Hydrology, 474, pp. 29-37.

Morgan, M., Strelein, L. \& Weir, J. (2004) Indigenous Rights to Water in the Murray Darling Basin (Canberra, Australian Institute of Indigenous and Islander Studies).

NAILSMA (2011) Background Briefing: Mataranka Indigenous Water Forum (15 August 2011) http://www.nailsma.org.au/nailsma/forum/downloads/Mataranka-BackgroundBriefing-16-8-11-web-2.pdf, retrieved 22 May 2012.

NAILSMA (2013) Indigenous people right to the commercial use and management of water on their traditional lands, Knowledge Series, Issue 17, Darwin, North Australian Indigenous Land and Sea Management Alliance).

National Water Commission (2011) The National Water Initiative - Securing Australia's Water Future: 2011 Assessment (Canberra, National Water Commission).

Nikolakis, W. (2011) Providing for social equity in water markets: the case for an Indigenous reserve in northern Australia, in: Q. Grafton \& K. Hussey (Eds) Water Resources Planning And Management, pp. 629-646, (London, Cambridge University Press).

O’Donnell, M. (2011) Indigenous rights in water in North Australia (Darwin, Northern Australian Indigenous Land \& Sea Management Alliance). 
Patton, M. (1990) Qualitative Evaluation and Research Methods (Newbury Park, California Sage Publications).

Richardson, T. (2005) Environmental assessment and planning theory: four short stories and power, multiple rationality, and ethics, Environmental Impact Assessment Review, 25 , pp. 341-365.

Rose D.B. (2004) Freshwater rights and biophilia: Indigenous Australian perspectives, Dialogue, 23, pp. 35-43.

Sandercock, L. (1995) Voices from the borderland: a mediation on a metaphor, Journal of Planning Education and Research, 14, pp. 71-88.

Strang, V. (2001) Negotiating the river: cultural tributaries in Far North Queensland, in: B. Bender \& Winer, M. (Eds) Contested Landscapes: Movement, Exile, Place, pp.69-86 (Oxford, Berg).

Strang, V. (2002) 'Life Down Under': water and identity in an Aboriginal cultural landscape. Goldsmiths Anthropology Research Papers, No. 7 (London, Goldsmiths).

Strang, V. (2007) Integrating the social and natural sciences in environmental research: a discussion paper, Environ Dev Sustain, 11, pp. 1-18.

Syme, G. \& Hatfield-Dodds, S. (2007) Values attached to water and their shaping of understanding and communication of reform objectives and implementation, in: K. Hussey \& S. Dovers (Eds) Water and Australian Society, pp. 11-22 (Melbourne, CSIRO).

Tan, P., Bowmer, K. \& Baldwin, C. (2012) Continued challenges in the policy and legal framework for collaborative water planning, Journal of Hydrology, 474, pp. 84-91. 
Toussaint, S., P. Sullivan, Yu, S. \& Mulardy, M. (2005) Water ways in Aboriginal Australia: an interconnected analysis, Anthropological Forum, 15, pp. 61-74.

Tehan, M. (2003) A Hope Disillusioned, an Opportunity Lost? Reflections on Common Law Native Title and Ten Years of the Native Title Act, Melbourne University Law Review, 27, pp. 523- 571.

Thonemann, H. (1949) Tell the white man: the life story of an Aboriginal lubra (Sydney, Collins).

Weir, J. (2009) Murray River country: an ecological dialogue with traditional owners, (Canberra, Aboriginal Studies Press).

Young, I. (1990) Justice and the politics of difference (Princeton, New Jersey, Princeton University Press).

Yu, S. (2000) Ngapa Kunangkul: living water: Report on the Indigenous cultural values of groundwater in the La Grange sub-basin (Perth, Western Australian Water and Rivers Commission). 
Figure 1. Map of the Roper River catchment, the Mataranka Water Plan area and other local features

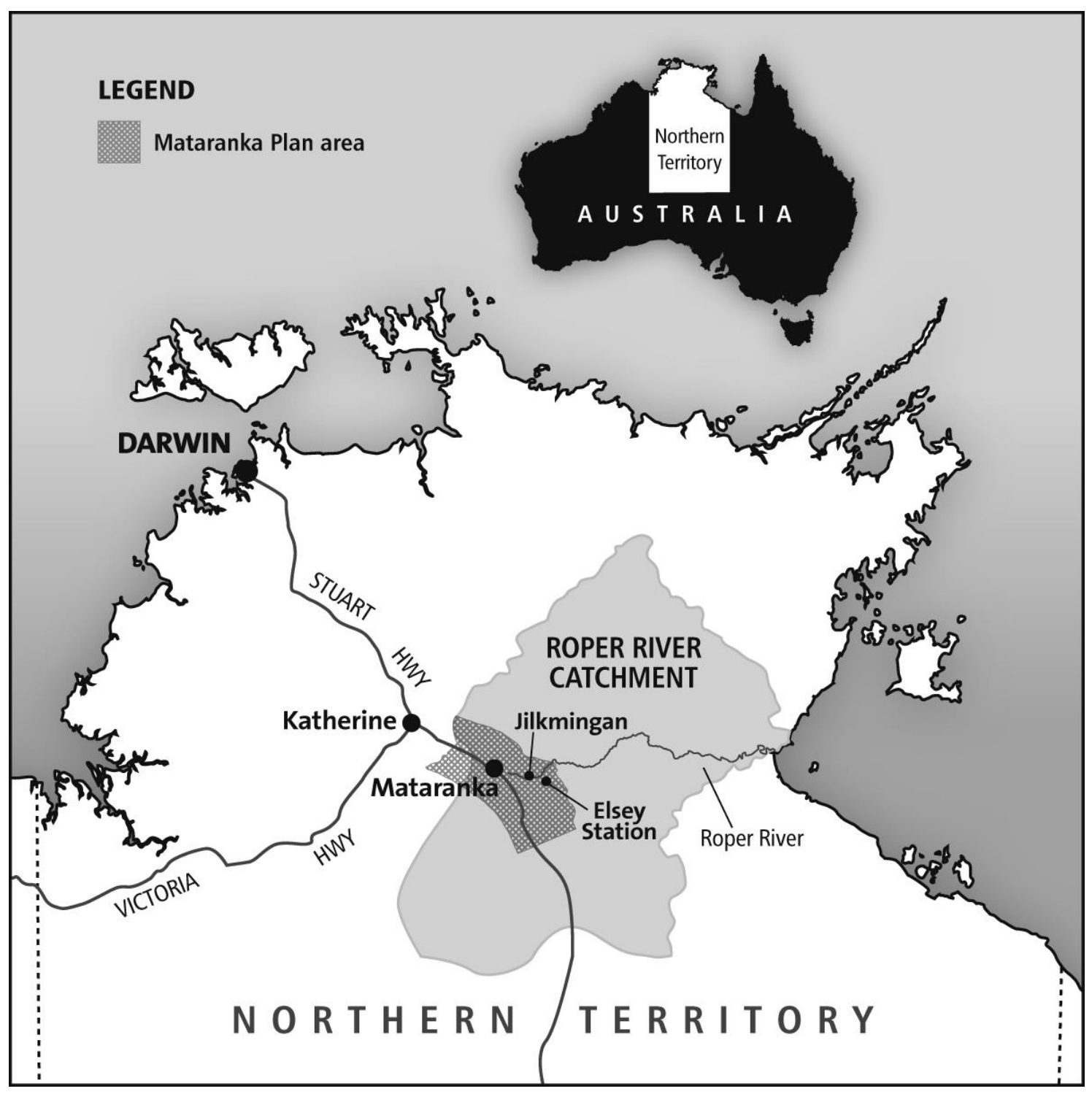

